\title{
エレベータ個性化群管理システムとその支援装置
}

\begin{tabular}{|c|c|c|c|c|c|}
\hline 会員 & 飛 & 田 & 敏 & 光 & （日 \\
\hline 非会員 & 藤 & 野 & 篤 & 哉 & （日 \\
\hline 正 員 & 米 & 日 & 健 & & \\
\hline$\Delta$ & & & & & \\
\hline
\end{tabular}

\section{Characterized Supervisory Control System for Elevators and its Support Equipment}

Toshimitsu Tobita, Non-member, Atsuya Fujino, Non-member, Kenji Yoneda, Member, Takaaki Ueshima, Non-member (Hitachi Ltd.)

An elevator group supervisory control system is used to supervise multiple elevators, ensuring that they are operated efficiently. In a conventional system which adopts the viewpoint of improving service to passengers, occurrence of hall calls is supervised and a call is assigned to the optimum elevator in consideration of the entire service condition, thereby reducing average waiting time.

Recently, requests by elevator users have focused not only on reducing average waiting time, but also on reducing riding time, the number of passengers, etc.

This paper describes a new elevator supervisory control system which improves plural control objects (reducing waiting time, riding time, number of passengers, etc.), according to owners' or managers' requests.

This system consists of a supervisory controller which supervises elevators, and support equipment. This support equipment receives' owners or managers' requests, and produces a control method which satisfies the control objects by using an expert system, and estimates results by simulation.

\section{キーワード：エレペータ，群管理，ファジー，意志決定支援}

\section{1. まえがき}

複数台のエレベータの運行管理を行うためのエレペ 一タ群管理システムの目的は, 利用者へのサービス向 上である。従来の群管理におけるサービス向上とは， 主に乗り場て，呼びボタンを押してからエレベータが 到着するまでの，乗り場における待ち時間を短縮する ことであり，これを実現するために様々な努力がなざ れてきた。例えば，マイクロコンピュータを用いて各 煊の予測待ち時間を計算し, ホール呼びが発生するご とにサーピスエレベータの決定を行うホール呼び割当 方式が研究され，一般に行われている(1)。この割当評 価の方式として, 待ち時間最小化方式, 長待ち最小方
式(2)，心理的待ち時間を考慮した方式(3)などが提案さ れ実用化されている。また，以上のような評洒方式で 割当てを行うときに，事前に設定した評価式を用いた のではビル内の交通流変化に対応できないため，ビル 内の交通流を学習し、これに基づいて評洒式のパラメ 一夕を改善してゆく方式も実用化されており(4)，更に 近年は，評価式による呼び割当て以外にもファジー制 御や知識処理, ニューラルネットを応用して待ち時間 の改善を行う方法も提案され，一部実用化されてい $z^{(5) \sim(8)}$ 。

以上述ベたように，従来のエレベー夕群管理システ ムの制御目標は, 待ち時間の短縮であり, 補助的に省 エネなどが行われているにすぎなかった。 
ところが，近年エレベータに対する利用者の要望事 項も単に待ち時間の短縮にとどまらず，「エレベー夕 に菜ってから目的階に到着するまての萧車時間を短縮 したい」とか，「すいてるエレベータに莱りたい」と いったように，様々な要求が出されるようになってき た。そこで, 各ビルごとに異なる個性的な群管理制御 を夷現できるシステムを提案した ${ }^{(\theta)(10)}$ 。このうなシ ステムでは，顧客の要求をどのように取入れるかが重 要であり，このために願客の要求からそれを渾たす制 御方法を決定する支援装置を用意している。本論文で は，個性化群管理システムのシステム構成抽よび個性 化支援装置の制御方法決定方法について埌告する。な お，ここにおける䫏笿とは，エレベータの個々の利用 者ではなく，ビルのオーナや管理者であり，個々の利 用者の要求の代表者である。

\section{2. 個性化制御方法とシステム構成}

群管理制御が行われるエレペータシステムでは，通 常 4 台〜8台のエレベータを 1 グループとして群管理 制御を行っている。群管理を行うエレベータの㱫成を 図1に示す。各階のホール呼びボタンの呼ひ情報は, 群管理制御装置に集められ，群管理制御装置は，この 呼び情報やかごの位䈯などから，割当てかごを決定 し，呼びを各号機制御装䈯に伝達する。号機制御蓄置 は、この割当てに従ってエレベータを制衔する。

待ち時間短縮のために割当号機の決定に用いられる 制当評価式を簡単に裁すと（1），(2)式になる。

$$
\begin{aligned}
& \Phi_{i}=h\left(t_{w i j}\right) \\
& \Phi_{e}=\min \left[\Phi_{1}, \Phi_{2}, \cdots, \Phi_{n}\right]
\end{aligned}
$$

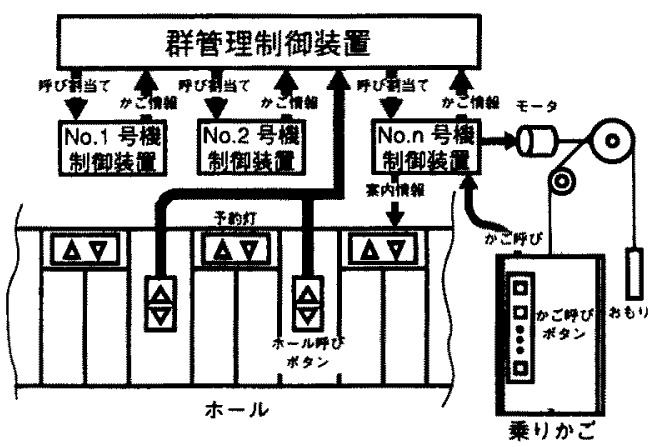

図 1 エレベータ群管理システムの構成 Fig. 1. Configuration of an elevator group supervisory control system.
あり(3)式て計算される， $\boldsymbol{\emptyset}_{i}: i$ 号機の評価

值, $h(x)$ : 謤価成数， $\omega_{a}$ : 各号機評価值

最小值

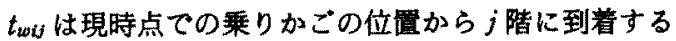
\&ての予测待ち時間 $t_{m i j}$ と $j$ 階の呼びが発生してから 現時点までの経過時間 $t_{p i j}$ の和で表される。

$$
t_{w i j}=t_{m i j}+t_{p i j}
$$

(2)式ては（1)式で計算された評価值の，の最小值 $\emptyset_{e}$ を求め，この最小值 $\emptyset_{e}$ をもつエレベー夕 $e$ 号機 を制当てエレベータとして選択する。

長時間待っている利用者へのサービス向上を図る長 待ち最小方式の場合，（1)式は次のようになる。

$$
\emptyset_{i}=\max \left(t_{w i j}\right)
$$

從って長待ち最小方式ては，(4)式から各号機の最大 予测待ち時間を各号機の評価值とし，この評価值 $\Phi_{i}$ が最小なる評価值 $\emptyset_{e}$ をもつ $e$ 号機を選択することに よって長待ちの最小化を図っている。

このほかに，满員になる確率や，予測のはずれる確 率，エレベー夕を分散させるたかのパラメータなどを この割当評価式に加味してサービス性を向上させる方 式がある。これら従来方式では，群管理の制御目標は あくまでも待ち時間の短縮を主として考えており，以 上述へたような項目を割当評洒式に追加することによ って，満真て通過したり予測がはずれたりすることて 待ち時間が増加することを抑制している。

このような方式によって待ち時間の短縮を図ってき たが，近年のビルの用途の多様化に伴ってエレペータ に求められる顧客の要求も表 1 に示したように様々な ものがでてきた。このような要求の多様化に対応する ために，エレベータの群管理制御も従来のように待ち 時間の短縮，という殚一の目標を満たすたけでなく， 車車時間やかご内混雑度なども含め, 殿客の要求に従 って制御する必要がある。以下，これら顧客要求のう ち待ち時間, 乗車時間, 加ご内混雑度の三目標を碓客

\begin{tabular}{|c|c|c|}
\hline No. & 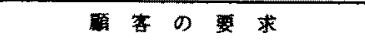 & 制誨目霜 \\
\hline 1 & 早く萧りたい & 特与時閔 \\
\hline 2 & 事っている時間を少なくしたい & 乗時間 \\
\hline 3 & すいたエレベータに番りたい & かご内混蜼度 \\
\hline 4 & 多くの人を㯰びたい & 遂能力 \\
\hline 5 & 予約したエレヘーータが早く来てはしい & 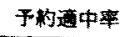 \\
\hline
\end{tabular}
要求にしたがって制御する方法について説明する。

図 2 は，待ち時關，乗車時間，かご内混赫度を重視

表 1 顧客の要求

Table 1. Request of owners or managers. 


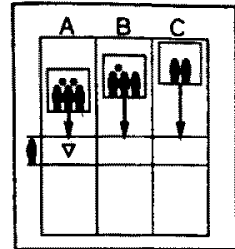

(a)待方時闑重䘽

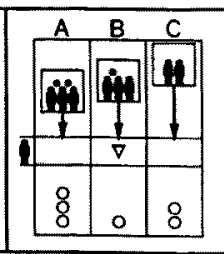

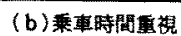

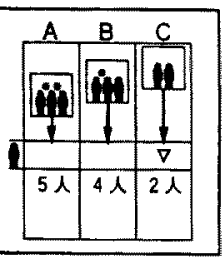

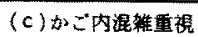

図 2 顧客の要求に応じたエレベータの 割当乙

Fig. 2. Examples of call assignment complying with requests of owners or managers.

するといった顧客の要求を受入れた制御を行う場合の エレベータの㓶当て方法を示している。图中○印は, かご呼びなどで既に停止することが決まっている階を 示しており， 印は割当てられたエレベータを示して いる。（1）式で表されるような従来の割当方式で， 待ち時間を佰先した割当方式となるので, 図 2 に示し たように混んでいても近くにあり，速やかに到蕃する Aが割当てられる。ところが，乘車時間を重視する なら(b)図のように，最下階に行くまてに，すでに 2 回停止することが決まっているAよりも，最下階 まで停止しない $B$ を割当てたほうがよく，混雑度を 重視するなら(c)図に示したように，多少到着が羊く なってもすいているCを割当てるべきてある。この ように待ち時間以外の制御目標を考慮するには，(1) 式のような評価関数では無理がある。そこで, 評価式 に乗車時間や，かご内混雑度といった評洒したい制御 目標に関する量を加えた（5)式のような割当て評価 式を用いる必要がある。

$\Phi_{i}=h\left(t_{w i j}, t_{r i j}, w_{r i j}\right)$

ここで, $t_{\pi i}: i$ 号機のj階から乗った人の子

測乗車時間, $w_{r i j}: i$ 号機の $j$ 階での予測菜 車率 (乗車人数/定員)

$こ の w_{r i j}$ の統計值として，かご内混雑度が算出され る。かご内混雑度は以下の式で定義した。

\section{定員の $50 \%$ 以上で起動した

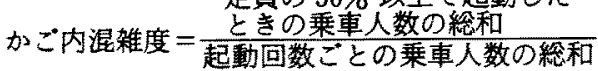

つまり，定員の $50 \%$ 以上の状熊で出発したときの 乗車人数を，出発するごとに合計した乗車人数すなわ ち全起動ごとの乗車人数の合計で割ったものであり， 定員の $50 \%$ 以上の混雑状況を体験した延へ人数の全 延べ乗車人数に対する比率を表している。

厡客要求に応じて最適な（5）式を決定すればよい

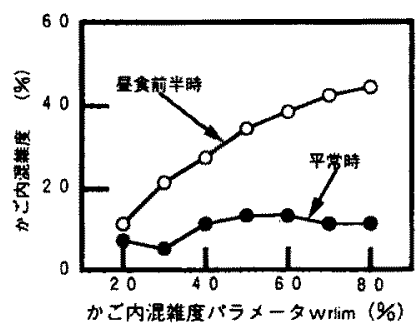

図 3 かご内泿嚾度パラメー夕 wrlim の效果 ((7)式 $f_{\text {w }}$ 内のパラメータ)

Fig. 3. Effect of crowdedness parameter.

が，エレベータの群管理では特別な場合以外解析的な 解は求まらない。そこで、シミュレーションにより （5）式を决定するため，（5)式を各制御目標に関する 量の関数の和で表すことにした。

$$
\begin{aligned}
\Phi_{i}= & k_{t w} f_{t w}\left(t_{w i j}\right)+k_{t r} f_{t r}\left(t_{r i j}\right) \\
& +k_{w r} f_{w r}\left(w_{r i j}\right) \ldots \ldots \ldots \ldots
\end{aligned}
$$

ここで, $k_{t w}$ : 待ち時間の係数, $k_{t r}$ : 乗車時 間の係数, $k_{w r}$ : 乗車率の係数, $f_{t w}$ : 待亏時 間の評価関数, $f_{t r}$ : 乗車時間の評洒関数,

$f_{w \tau}$ : 垂車率の評価関数

この係数 $k_{t w}, k_{t r}, k_{w r}$ および評価関数 $f_{t w}, f_{t r}, f_{w r}$ を 要求に応して変化させることによってビルごとに異な る群管理制御を行うが，これらを変化させたとき，ど の程度制御目嫩を変化させることができるかの一例を 示したものが図 3 である。ここでは $f_{w r}\left(w_{r i j}\right)$ は次の ような咸数である。

$$
f_{w r}\left(w_{r i j}\right)=\left\{\begin{array}{l}
f_{w r}\left(w_{r i j}\right)=w_{r i j}\left(w_{r i j} \leqq w_{\tau 1 i m}\right) \\
f_{w r}\left(w_{r i j}\right)=w_{r i j}+w_{p n}\left(w_{r i j} \geqq w_{r 1 i m}\right)
\end{array}\right.
$$

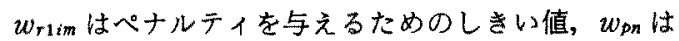
ベナルティ值である。

图 3 はかご内混雑度を制御するための乗車率の評晌 関数 $f_{w r}$ に含まれるパラメー夕 $w_{r i i m}$ を，20〜80まで 変化させたときのかご内混雑度の変化を示しており, ○印が昼食前半時の交通流，一印が平常時の交通流の 場合である。図からかかるように，（7）式の評価関数 や，係数の影蝤は一定ではなく，またビル内の交通流 にも大きな影㲎を受けるため，解析的に決定するのは 困難である。そこで，各ビルごとに個性的な制御を実 現するために顧客の要求を取入れ，ビル内の交通流や ビルの用途なども考虑して，具体的な制御方法を決定 するための支援装置を設けることにした。 


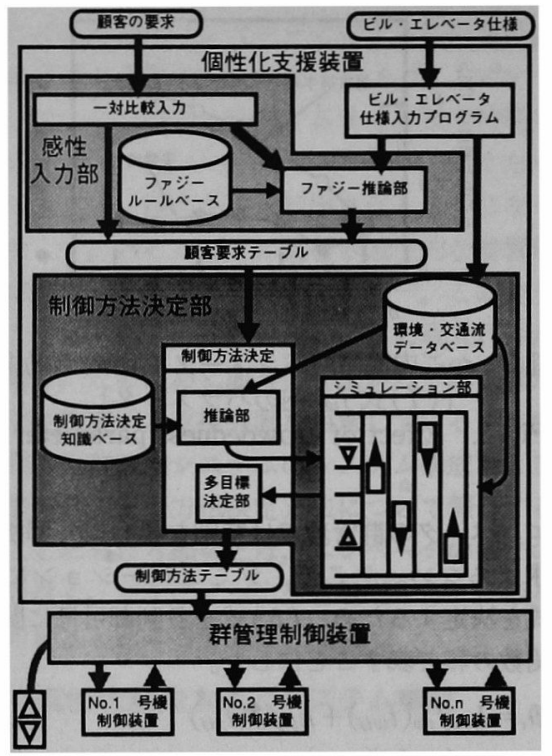

図 4 個性化群管理システムの全体構成 Fig. 4. Configuration of an elevator characterized group supervisory control system.

\section{3. 個性化支援装置と推論方法}

図 4 に個性化支援装置を備えた群管理制御装置の構 成を示す。個性化支援装置は, 顧客の定性的な要求を ビルの特徵やエレベータの仕様を考慮して数值化する 感性入力部と, この数值化された顧客要求を実現する 制御方法を決定するための制御方法決定部で構成 した。

定性的な顧客の要求は感性入力部の一対比較入力部 で受け入れ，ファジー推論部で, ビル・エレベータの 仕様を考慮して数值化し, 顧客要求テーブルとして出 力する。制御方法決定部では, この顧客要求テーブル を満たすような制御方法の候補を推論部で制御方法決 定用知識ペースの知識をもとに, 環境・交通流データ ペースのデータを考慮して推論し, シミュレーション 部で各制御方法の候補を用いてシミュレーションす る。多目標决定部では, 各候補のシミュレーション結 果を顧客要求テーブルの内容を用いて比較し, 顧客要 求をもっとも良く満たすものを制御方法テーブルとし て出力する。このとき, 予測結果を出力するので, 結 果を見て要求を変更することができる。

〈3・1〉 感性入力部感性入力部は, 定性的な顧 客の要求を数值化するものである。数值化した顧客要 求は $(9)$ 式の重み付けノルムの式で表し,これを制御

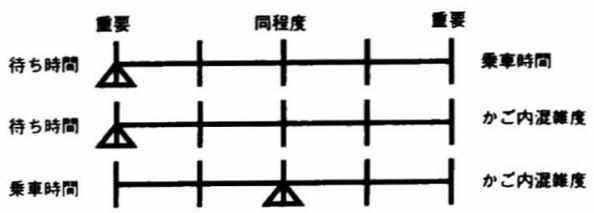

図 5 一対比較入力方法

Fig. 5. Example of input method of owners' or managers' requests.

方法を選択する際の評価指標とすることにした。

$$
l_{p}=\Sigma w_{i}\left|f_{i}-\widehat{f}_{i}\right|
$$

ここで, $l_{p}:$ 重み付けノルム, $w_{i}:$ 重み係

数, $f_{i}$ : 予測達成値, $\hat{f}_{i}$ : 目標値

感性入力部は図 4 のようにファジー推論部と一対比 較入力部で構成した。この重み係数や, 目標値の入力 方法は, 種々考えられるが, 直接数值を入力する方法 は非常に難しい。例えぱ，エレベータの台数が限られ ているとき, 待ち時間の要求を満たそうとすれば, か ご内混雑度の要求を, 満たすことができないといった ようなことが生じ, 多目標間のバランスのとれた妥当 な要求を入力することが困難である。そこで, エレべ 一夕の能力を分配するという考えから，図５のように 各制御目標を一対一で比較し，それぞれ，どちらがど れだけ重要と考えるかを三角形の位置で示し，この位 置を数值化して固有ベクトル法(11) を用いて, それぞ れの制御目標の重要度 $a_{i}$ を求めることとした。例え ば, 図 5 の最上部の三角形は待ち時間を乗車時間に比 べ特に重要と考えることを表している。

この值 $a_{i}$ は, ビルの用途や交通流について考慮さ れていないので, これをそのまま重み係数 $w_{i}$ とする ことはできない。そこで( 9 )式の重み係数 $w_{i}$ を(10) 式のように重要度 $a_{i}$ とビルの用途・交通流などから決 まる換算係数 $\beta_{i}$ の積で表すことにした。次にこの 換算係数の求め方について説明する。

$$
w_{i}=a_{i} \beta_{i}
$$

換算係数 $\beta_{i}$ は, ピルの用途や, 交通流によって乗 車時間の 1 秒, かご内混雑度の $1 \%$ を待ち時間何秒分 相当とするかを表す数字であり, 制御方法を様々に変 化させたときの制御結果の最大值, 最小値を基に求め るが, シミュレーション前にこれを得ることはできな い。更に, 事務所ビルとホテルでは, 同じ待ち時間重 視を選択してもその程度が異なる。そこで, 換算係数 $\beta_{i}$ をビルの種類や交通流などからファジー推論によ って求めることにした。また，目標値は，制御結果の 最小值とするので, 目標値 $\hat{f}_{i}$ も同様にファジー推論 で求めることにした。 


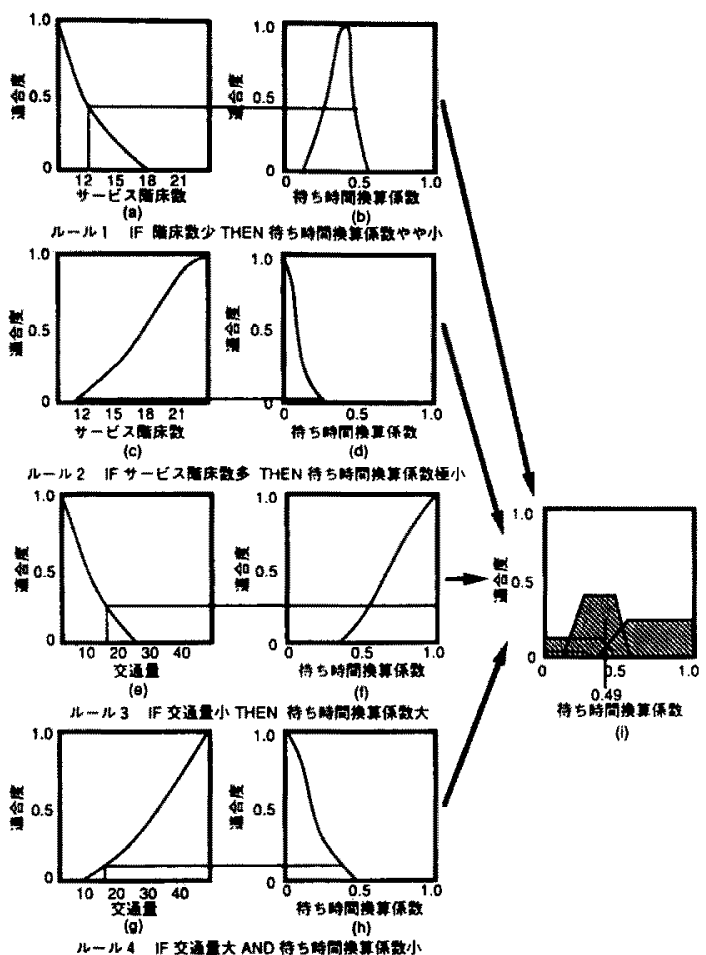

図 6 ファジー推論部の動作例

Fig. 6. Example of fuzzy resolution.

次に，図6の例を用いてファジー推論の方法を説明 する。ここでは，待ち時間の換算係数を求める方法を 例にあげる。条件は，サービス階床 12 階床，交通量 15 人/(5 分・台 $)$ とる。まず,ルール1「IF 階床数 少 THEN 待古時間換算係数やや少」の前提部のメ ンバシップ関数 $(a)$ とサービス階床 12 階木を照らし 合せて適合度 0.44 を得る。この適合度のところで， 結論部のメンバシップ関数をカットする。ルール2, 3，4 についても同様の操作を行い，カットした結論 部のメンバシッブ関数をすべて重㭘せ，(i)のメン バシッブ関数をつくり，この重杍合せたメンバシップ 関数の最大值で囲まれた図形 (ハッチングを施した部 分）の重心を求め，この重心の横軸座標を待ち時間の 㒀算係数とする。ここでは，0.49である。赛行可能 な制御方法をすべてシミュレーションして得た換算係 数の実験値は, サービス階床 12 階床, 交通量 15 人/ ( 5 分・台)のとき 0.48 であるから, ほほ正確な值が得 られている。

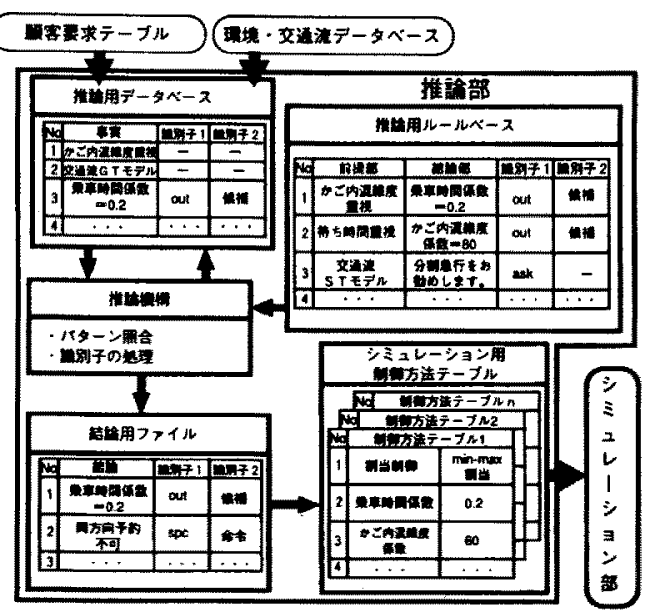

図 7 推 論 部

Fig. 7. Reasoning unit.

〈3.2〉制御方法決定部 感性入力部て作成した 顧客要求を満たす制御方法を決定するための評洒指標 に，もっとも適した制御方法を求めるのが制御方法決 定部である。重み付けノルムで表された評価指標 (9) 式を与えられたビル・エレべータ仕様の条件で最小に するような(7)式のパラメータを求めるのだが，ビ ル・エレベータの仕様は，納め先によって紐かく違い, また特殊な場合をのでき解析的に扱えない。

更に，顧客が得られたシミュレーション結果を見る ことにより要求を変更したり, 場合によっては, エレ ベータの速度, 定員, 台数といったエレべータの仕様 を変更したいという要望を出すことも考えられる。そ こで, 解析的に求まら京いことについては, 過去のシ ミュレーション結果などから作成した知識を用いて推 論によって制御方法の候補を幾つか求め，その制御方 法の候補を用いて群管理制御を行った場合のシミュレ ーションを行い，その結果を(9)式に代入してその值 のもっとも小さいものを選択し，結果を表示，顧客は この結果を見て良否を判断できるようにした。

この推論システムは，図７に示すように前向き推論 を行うプロダクションシステムである。

推論用ルールベース内のルールは, 推論結果をもと にシミュレーションを行うために前提部，結論部の他 に推論結果である結論部の使用方法を表す識別子 1 , 結論部のシミュレーションでの使われ方を表す識別子 2 をつけ加えた四つの部分て構成した。 


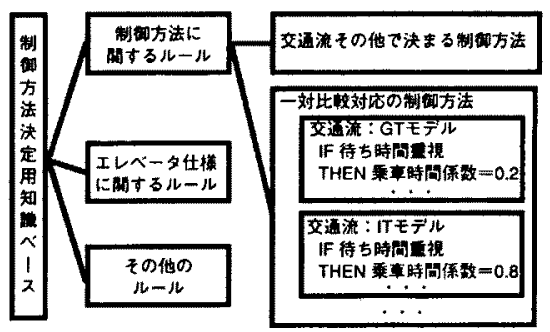

図 8 制御方法決定用知識ベースの構造 Fig. 8. Rule base structure of reasoning unit.

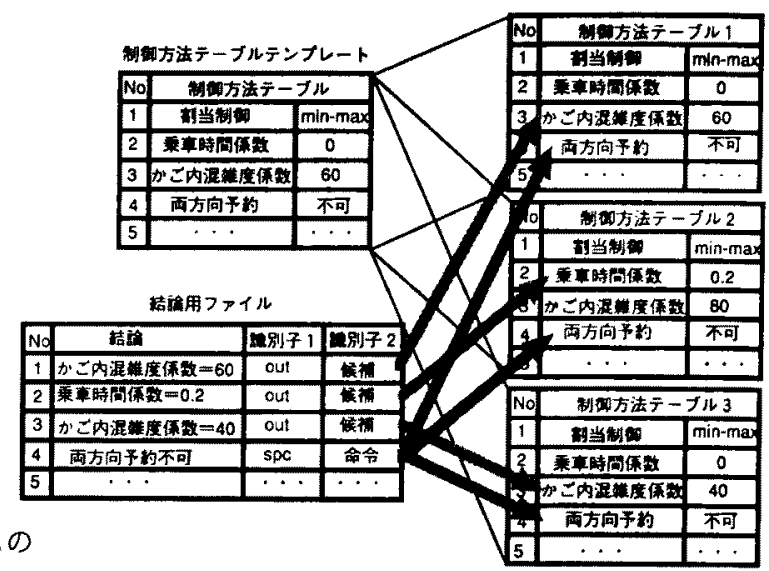

図 9 制御方法テーブルの作成方法

Fig. 9. Creation method of control table.

ンを行うには，推論されてくるもの以外のすべてのパ ラメータが決定していなければならない。そこで, 図 9のようにあらかじめ標準的なパラメータを納めたテ ンプレートを用意しておき，推論結果によってこのテ ンプレートの該当する項目を書き換える。識別子 2 に “候補”とあった場合は，テンプレートから新しいシミ ユレーション条件である制御方法テーブルをつくり, 該当する部分を推論結果で置き換える。識別子 2 に “命令”とあった場合は，すべてのシミュレーション条 件の該当する箅所を書き換える。これは主に“両方向 予約の可否”や“交通量が多いときは乗車率のパラメー タを大きくしない”といった利用者が決定する条件ゃ 禁止事頁である。

“両方向予約”とは一つのエレベータが上向きと下向 き両方に予約され，上下両方向の予約灯が点灯する場 合で，2階て上りと下りのボタンを押したとき，ある エレベータが下りをサービスしてから，上りもサービ スしたほうが, 他のエレベータがサービスするよりも 効率が良くなる場合などに発生する。両方向予約を行 ったほうがエレベータの効率は良くなるが表示がまぎ らわしくなり, 乗り間違いなどが発生するので,これ を実行するには，㕍客の許可が必要となる。

以上のようにして作成した制御方法テーブルを用い てシミュレーション部でシミュレーションを行い, 多 目標决定部で，その結果を(9)式に代入して比較，表 示する。顧客はこの結果を見て良否を判断し，結果が 納得できないときは一対比較などの入力を㚆更するこ とによって納得できるまでやり直すことができる。こ のようにして顧客の要求に従った制御方法を決定する ことがでる。 


\section{4. 個性化支援装置の使用例}

図 10 は支援装置による個性化結果である。同図右 上の一対比較入力て待ち時間，乗車時間，かご内混雑
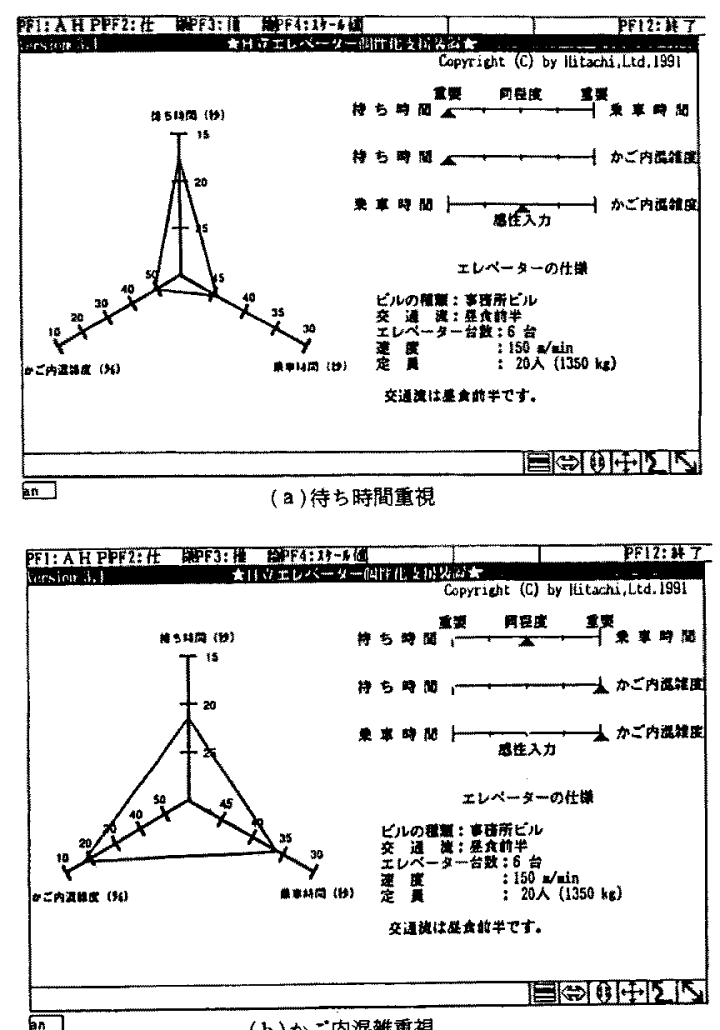

図 10 個性化結果

Fig. 10. Examples of characterization results.
度それそれれ方を，他方に比べてどれだけ重視するか を三角カーソルを移動することによって入力する。フ ワンクションキー2 を押すとエレベータの仕様を変え ることができ，定貝や，エレベー夕速度を変えた場合 の比較も行うことができる。(a)図は待ち時間を最 重視した場合の個性化結果であり, 待ち時間は 17.1 秒とよいが, 乗車時間 44.3 秒，かご内混雑度 $49.0 \%$ で約半数の人が混雜を体験している。(b)図はかご 内混雑度を最重視した結果て, 待ち時間は, 21.8 秒 と(a)図に比べて 4.7 秒军くなっているが，乗車時 間は， 35.7 秒，かご内混雑度は, $17.3 \%$ と大幅に改 善されれている。

図11はそれぞれの場合のある乗りかごの乗車人数 の推移を示している。（a )図の待ち時間重視の場合 は，乗車人数は考慮していないので，10人以上で起 動した回数が 10 回あり,そのうち 2 回満員が発生し ている。これに対し，(b)図のかご内混雑度重視の 場合は, 10 人以上で起動した回数は，5回と半分に なっている。これは，ほかの乗りかごについても同様 で, 待ち時間重視の場合, 10 人以上で起動した回数 が 6 台合計で 42 回であったが，かご内混雑度を重視

表 2 個性化シミュレーション条件

Table 2. Simulation condition.

\begin{tabular}{|c|c|}
\hline \multicolumn{2}{|c|}{ シミュレーショシ条件 } \\
\hline ビルの種類 & 事移所ビル \\
\hline 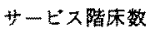 & 15踷坤 \\
\hline エレベータ台数 & 6 台 \\
\hline エレペータ遴度 & $150 \mathrm{~m} / \mathrm{min}$ \\
\hline エンペータ定買 & $20 人$ \\
\hline 交 通 嘿 & $140 大 / 5$ 分 \\
\hline
\end{tabular}

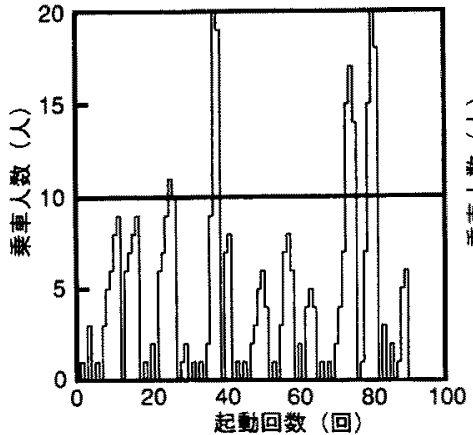

(a) 待方時間恶視

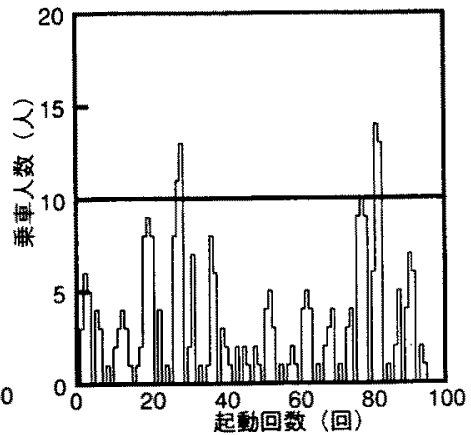

(b)かこ内混襍重視

図 11 乗降人数の推移

Fig. 11. Change in number of passengers. 
した場合には 24 回になり，満員は発生しなくなった。 以上述べた個性化シミュレーションの条件を表 2 に 示す。

以上より，支援装置を使用することにより待ち時間 を重視すれば, 待ち時間の良い制御方法を, かご内混 雑度を重視すれば, かご内混雑度の良い制御方法を選 択でき, 顧客の要求に応じた制御が実現できることが わかる。

\section{5. まと め}

エレベータの群管理システムとして, 従来からの待 ち時間の短縮ばかりでなく, 乗車時間や, かご内混雑 度について顧客の要求を受け入れて群管理制御する個 性化管理システムを開発した。その顧客要求を受け入 れるためのファジー推論とプロダクションシステムお よびシミュレーションを組合せて対話的に個性化支援 装置を作成し，その効果を確認した。

(平成 3 年 4 月 25 日受付, 同 3 年 9 月 19 日再受付)

\section{文献}

（1）弓仲，他：「エレベータ群の予測制御システム」, 日立評論, 54, 67 (昭 47-12)

（2）平沢, 他:「エレペー夕群管理における呼び割付方式」, 電学 論 C, 99, 1 (昭 54-2)

（3）渡辺，他「高速エレベー夕の速度制御と群管理」、システムと 制御, 22, 316 (昭 53-6)

（4）黒沢, 他:「エレペー夕の知能群管理方式一その 2 : 学習論理 -」, 情報処理学会論, 28, 299 (昭 62-3)

（5）安信, 他: 「予見 Fuzzy 制御によるエレベータ群管理方式の 提案」, 第 26 回計湘自動制御学会学術講演会 (昭 62)

（6）匹田，他「ファジィ・ルールベースを用いた新しいエレペー 夕群管理システム」, 計測自動制御学論, 25, 99 (昭 64-1)

（7）春木，他:「エレベータ群管理システム Fuzzy 制御システム とその知識抽出」, 第 14 回システムシンポジュウム講演論文 集, p.79 (昭 63)

（8）匹田，他：「ニューラルネットワークを応用したエレペータ 管理方式の提案」, 第 15 回システムシンポジウム第 10 回知 識工学シンポジウム合同シンポジウム, p. 267

（9）森田, 他「エレベー夕個性化群管理システム」, 昭 63 電気学 会全大, p. 2120

（10）飛田, 他：「多目標なエレベー夕個性化知能群管理システム の制御方法決定手法」, 第 31 回自動制御連合講演会, p. 475 (昭 63)

（11）「多目標意志決定-理論と応用- 一多目標意志決定と AHPJ, システムと制御, 30, 38 (昭61-7)

（12）藤野，他：「エレベーター群管理における交通流のモデル化 と制御」, 情報処理学会第 39 回全大(III), p. 2272 (平元)

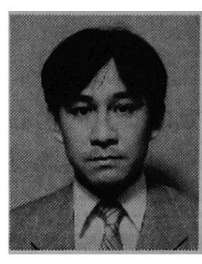

\section{飛 田 敏 光 (非会員)}

昭和 58 年千葉大学大学院工学研 究科機械工学第二学科修了。同年 (株) 日立製作所日立研究所入社。現 在, 日立研究所第 10 部 104 研究室 に所属。エレベー夕関連の研究開発に従事。

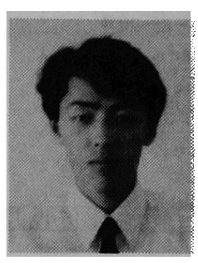

\section{藤 野 篤 哉 (非会員)}

昭和 62 年北海道大学工学部電子 工学科卒業。同年(株) 日立製作所日 立研究所入社。現在, 日立研究所第 10 部 104 研究室に所属。エレベー 夕群管理の研究開発に従事。

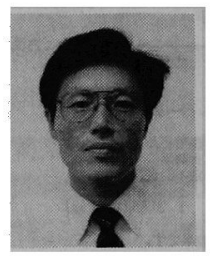

\section{米 田 健 治 (正員)}

昭和 40 年富山県立破波工業高等 学校電気科卒業。同年(株) 日立製作 所水戸工場入社。現在, 水戸工場工 レベータ設計部に所属。主として, エレベー夕群管理システムの開発に従事。

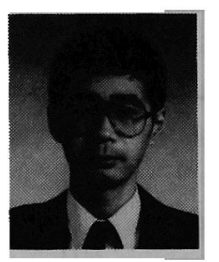

\section{上島孝明 (非会員)}

昭和 54 年早稲田大学理工学部電 気工学科卒業。同年(株) 日立製作所 入社。現在, 水戸工場エレベータ設 計部所属。主として, マイクロコン ピュータ応用エレベータの開発に従事。 